\title{
The Position Of Islam In Foreign Policy During President Joko Widodo's Government (2014-2019)
}

\author{
Erianto \\ Program Studi Hubungan Internasional UIN Alauddin Makassar
}

\begin{abstract}
Indonesia is the $4^{\text {th }}$ most largest population in the world, $87 \%$ of 260 million people in Indonesia is a Muslim. Indonesia is the country with the largest Muslim religion in the world, but Indonesia is not a Islamic State. Domestic political conditions influence on foreign policy. Indirectly, what happens in the country influences foreign policy issued. The author use a qualitative methodology to analyze the issue. So, the result of this research is to show the extent to which Islam influenced Indonesia's foreign policy,especially during the President Jokowi government. About how the style of President Jokowi's government in responding to domestic issues that attacked the government. This study also discusses how interest groups bring their interests to influence a policy that is produced.
\end{abstract}

Keywords :

Islam, Jokowi, Interest Group, Foreign Policy, and Politics

\section{THE PREFACE}

Indonesia is the 4th most populous country in the world after the United States America with a population of around 260 million people. $87 \%$ of 260 million people in Indonesia adhere to Islam, Indonesia is the country with the largest Muslim religion in the world, but Indonesia is not an Islamic state, Indonesia is a country with a presidential government system based on the 1945 Constitution of the Republic of Indonesia.

In 2014, the country with the largest Muslim population held a presidential election and Joko Widodo (Jokowi) was elected as President of Indonesia through a general election, Jokowi was considered fresh to the Indonesian political world because he did not have an elite background. The election is the most important momentum for Indonesia's foreign policy.

Domestic political conditions influence on foreign policy. Indirectly, what happens in the country influences foreign policy issued. Jokowi's Islam has been attacked since the 2014 presidential election, the defeat of Basuki Tjahaja Purnama in the 2017 Jakarta gubernatorial election was 
the beginning of strengthening the political identity of Islam in Indonesia.

The amount of pressure from within, especially those criticizing the Jokowi government. Many of these pressures criticized Jokowi for being less pro to Islam. Some of the critics even came from famous figures such as Deputy Speaker of the House of Representatives, Fahri Hamzah, who stated that Jokowi was an anti-Islamic person and many of his policies smelled of Islamophobia. ${ }^{1}$

From the many pressures to the emergence of large demonstrations which essentially criticized the Jokowi Government, some even thought that Jokowi did not accommodate Islam as a religion in Indonesia anymore. Demonstrations that occur familiarly known as 'Islamic action', the action has even become a routine agenda every year on a certain date. Since 2016 there have been seven actions on a fairly massive scale.

What is produced by the criticism of these figures who are the role models of the community has a big impact on the community itself, which in turn gives the image of Jokowi's government to be unprofitable. Like when there were many expressions of hate and fake news on social media. The message to be conveyed is that a Muslim must not have a leader

\footnotetext{
${ }^{1}$ Wishnugroho Akbar, "Fahri Kicaukan 'Dosadosa Jokowi' soal Ideologi dan Persatuan" in https://www.cnnindonesia.com/nasional/20180723 171304-32-316365/fahri-kicaukan-dosa-dosajokowi-soal-ideologi-dan-persatuan accessed on 12 November 2019.
}

who is not pro-Islamic, giving rise to the perception that the Jokowi government is harmonizing Islam in Indonesia. In addition, the strongest message is that a Muslim must not be led by a non-Muslim. It is not uncommon to assume that Jokowi is just a 'puppet' president who is driven by a group of people with interests behind him.

This is strange in Indonesia, even though there has never been anything like it before. The existence of such phenomena creates an inevitable split of opinions from the Islamic community in Indonesia. The pressure is averaged from the Muslim community. But not a few Muslim communities who support and defend the actions of the Jokowi government. One example is the Former Muhammadiyah Central Leader, Ahmad Syafii Maarif, or better known as Buya Syafii, who stated to stop all assumptions that Jokowi paid less attention to Islam. ${ }^{2}$ As a result, both parties feel most righteous and accuse each other even though both are equally Muslim, and this is something that should not be done by fellow Muslims.

What is questionable is how Jokowi positioned Islam in determining policy, especially foreign policy. Given the magnitude of domestic pressure, especially from the Muslim community who think that Jokowi ruled out Islam. So far the

\footnotetext{
${ }^{2}$ Pribadi Wicaksono, "Buya Syafii Minta Hentikan Bilang Jokowi Kurang Perhatikan Islam" in https://nasional.tempo.co/read/1152805/buyasyafii-minta-hentikan-bilang-jokowi-kurangperhatikan-islam/full\&view=ok accessed on 12 November 2019.
} 
Jokowi government has had a lot of impact on the divisions of the Muslim community which is a significant mistake. There are aspects of society that need to be seen so that we can know the extent of the role of Islam in determining the policies of the Jokowi government, especially foreign policy.

Before investigating further about the role of Islam in Indonesia's foreign policy, several literature reviews are relevant to this research, namely a study by Mangadar Situmorang entitled "Orientasi Kebijakan Politik Luar Negeri Indonesia di Bawah Pemerintahan Jokowi-JK." ${ }^{3}$ It was concluded that Indonesia's foreign policy under the Jokowi government was different from the previous administration. Under the Jokowi government, Indonesia will be more inward-looking which is partly due to domestic political pressure.

Besides, there is also research by Rizky Alif Alvian, Ganesh Cintika Putri, and Irfan Ardhani with the title "Haluan Baru Politik Luar Negeri Indonesia: Perbandingan Diplomasi 'Middle Power' Susilo Bambang Yudhoyono dan Joko Widodo." ${ }^{4}$ mention that President Yudhoyono and Joko Widodo proposed a

\footnotetext{
${ }^{3}$ Mangadar Situmorang, "Orientasi Kebijakan Politik Luar Negeri Indonesia di Bawah Pemerintahan Jokowi-JK", Jurnal Ilmiah Hubungan Internasional, Vol. 11 No. 1 (2015), pp. 67-85.

${ }^{4}$ Rizky Alif Alvian, Ganesh Cintika Putri \& Irfan Ardhani, "Haluan Baru Politik Luar Negeri Indonesia: Perbandingan Diplomasi 'Middle Power' Susilo Bambang Yudhoyono dan Joko Widodo", Jurnal Hubungan Internasional, Vol. 6, No. 2 (2017), pp. 151-168.
}

different vision regarding Indonesia's foreign policy, but both interpreted Indonesia's position as a middle power country. Using the issues of border and maritime diplomacy as well as democracy, Islam, and human rights as case studies, this article argues that Indonesia's middle power diplomacy strategy has shifted its orientation from - borrowing Krasner terminology - relational power to metapower. If Indonesia under Yudhoyono had previously sought to gain more profits by following established rules, Indonesia under Widodo is now trying to achieve its interests by influencing, changing or establishing rules in international politics.

And research by Mohammad Erzawan Wijaya entitled "Pengaruh Politik Luar Negeri Pemerintahan Joko Widodo terhadap Islam di Indonesia. ${ }^{5}$ mentioned that Joko Widodo's government contributed to Islam in Indonesia by fulfilling several aspirations related to the foreign policy of the Islamic community in Indonesia, although there were other motives behind it.

\section{RESEARCH METHODS}

Data collection is defined as a process of obtaining empirical data through respondents using certain methods. This research uses a literature study method for collecting data. Through this method, the data in this research are obtained through

${ }^{5}$ Mohammad Erzawan Wijaya, "Pengaruh Politik Luar Negeri Pemerintahan Joko Widodo terhadap Islam di Indonesia", Skripsi (Bandung: Universitas Katolik Parahyangan, 2019). 
the literature in the form of books, printed bulletins, and sources of articles from the internet that can be accounted for academically.

To explain how important the position of Islam is in Indonesia's foreign policy, especially during the administration of President Jokowi (2014-2019).

This research uses qualitative data analysis techniques, this is because the empirical data obtained is qualitative in the form of a collection of words and not a series of numbers. In the process of analyzing data according to Miles and Huberman states that there are three lines of activity in analyzing data namely data reduction, data presentation, and drawing conclusions or verification.

\section{RESULT AND DISCUSSION}

\section{Jokowi and The 2014 Election}

In 2014 Indonesia held a presidential election, this election was held to replace President Susilo Bambang Yudhoyono who has entered his third period, which according to Law Number 42 Chapter III of 2008 concerning the Requirements for Candidates for President and Vice Presidential Candidates and Procedures for Determining Candidates for President and Vice President, Part One concerning Requirements for Candidates for President and Candidates for President, Article 5 letter states that Candidates are for the President and Candidates The President has never served as President or Vice
President for 2 (two) terms of office in the same position. ${ }^{6}$

At that time the candidates for president and vice president were Joko WidodoJusuf Kalla and Prabowo Subianto-Hatta Rajasa. Elections were held on July 9, 2014 , with a total of $134,953,967$ voters participating, with $133,574,277$ valid votes. Jokowi-JK won the general election with $70,997,833$ votes collected, with a percentage of $53.15 \%$ or a $6.3 \%$ difference in votes from Prabowo-Hatta. ${ }^{7}$

The 2014 election is an important pillar for democracy as the modality of Indonesia's foreign policy when Indonesian democracy elects a new president without political violence. It is believed that Jokowi is the answer to all questions that arise about the Indonesian political stage, regarding all challenges in the country, in the form of the interests of groups in Indonesia who do not want to be ruled out.

\section{Jokowi's Style of Government}

Jokowi has a simple style of politics, this is shown through his simple appearance. Trying to understand the problems that

${ }^{6}$ DPR RI," Undang-Undang No.42 Tahun 2008 Tentang Pemilihan Umum Presiden dan Wakil Presiden" in http://www.dpr.go.id/dokjdih/ document/uu/UU_2008_42.pdf accessed on 12 November 2019.

${ }^{7}$ KPU RI, "Hasil Penghitungan Perolehan Suara Dari Setiap Provinsi dan Luar Negeri Dalam Pemilu Presiden Dan Wakil Presiden Tahun 2014" in https://www.kpu.go.id/koleksigambar/PPWP__Nasional_Rekapitulasi_2014_-_New_-

_Final_2014_07_22.pdf accessed on 12 November 2019. 
people face with 'blusukan', Jokowi also does not keep his distance from reporters, every time reporters are approaching, Jokowi certainly serves every question raised by reporters.

During the Jokowi period, foreign policy was more 'low profile' or at least reduced "too much appearing abroad" and would focus more on domestic affairs or be shown in the same way to fix and strengthen in "inward looking". According to Jokowi, the strengthening and development of the national economy seems more interesting and more important.

Jokowi spent more time building relationships with countries that are considered to benefit Indonesia directly. Jokowi has the vision and mission statement of foreign relations, namely "the realization of a sovereign, independent, and personality based on mutual cooperation". This vision reinforces the meaning of "freedom" in Indonesia by realizing national sovereignty, independence and personality. President Jokowi's administration laid the operational foundation of foreign policy as an effort to increase Indonesia's consistency in implementing a free and active foreign policy, and made the Indonesian state a

\footnotetext{
${ }^{8}$ Blusukan, is a Javanese word, which The Jakarta Post translated as a surprise visit, became very popular after it was used by Jokowi, the governor of Jakarta. Jokowi uses the word to describe his activities of conducting direct inspections, often without anyone knowing when and where he went, even without staff and journalists who always followed his movements to know where he was going.
}

maritime country to realize a better world order and fight for its national interests in order to achieve national goals. Jokowi's image as president was known as a "clean" president. Jokowi seems trying to separate matters relating to state affairs and personal matters. As was the case when his son graduated, Jokowi was reluctant to ride on a commercial plane, this was something that had never been exposed to the governments of previous presidents.

Another style of Jokowi is openness, which was observed during his tenure as President, Jokowi was not too concerned with the protocol. Jokowi is relatively easy to ask for an opinion. Openness for a political leader does have double consequences. Jokowi does not like to debate let alone be dramatic. As a Javanese, Jokowi is more concerned with harmony, this is following the noble values of the Javanese people who are more concerned with harmony than disputing. Seen here the style of government brought by Jokowi tends to be as it is, not dramatizing.

Hendri Satrio, a Political Communication Observer from Paramadina University supports the findings of the statement in Jokowi's memoir book ${ }^{9}$ and adds that President Jokowi always wants to be seen independently. Do not want to be directed or encouraged in making certain decisions. This characteristic appears in the appointment of certain officials. "If there

\footnotetext{
${ }^{9}$ Alberthiene Endah, Jokowi Menuju Cahaya (Surakarta: Tiga Serangkai, 2018).
} 
are too many who propose or mention the A, then it is certain that the A will not be chosen by President Jokowi." Said Hendri Satrio. According to him in this way, Jokowi showed the public that Jokowi had independence, and at the same time showed that he was a President. Additionally according to Hendri, the longer the level of confidence of President Jokowi is getting stronger, and this will further support his dominant nature.

Once observed, Jokowi's style of government tends to be more relaxed and open. Jokowi received various inputs from various groups of people who wanted to convey criticism and suggestions to his government. Jokowi also seemed independent when determining the policy to be issued, Jokowi did not seem to want to be disturbed. The form of policy issued does not burden or discriminate against one group. Unfortunately, this style is seen by Muslim societies as a style that is not pro-Muslim. If seen, Indonesia is not an Islamic State whose entire policies are pro-Muslim. Indonesia is a rule of law based on the 1945 Constitution of the Republic of Indonesia, where "social justice for all Indonesian people." no one must be ruled out because in truth all the Indonesian people are the same.

\section{The Most Influential Islamic Interest Group in Indonesia}

Interest groups first appeared in the early 19th century. In the past, interest groups were known as pressure groups, but there was an assumption that not all interest groups were emphasized. According to
Gabriel Almond, an interest group is an organization that aims and seeks to influence government policy, without requiring public office.

The most important characteristic of an interest group is that every activity carried out by an interest group will act on behalf of the community, considering that its function as an articulator or sorting out interests in the community turns it into a demand that will be directed at the government, or through other institutions such as political parties. The activities of interest groups tend to influence the government in making decisions about policies that will be issued.

With the largest Muslim population in the world, Indonesia certainly also has an interest group that carries Islamic-based interests. It is undeniable that there are many Islamic interest groups in Indonesia, they all bring their interests and demands to the government.

Of the many Muslim population in Indonesia, there are also many Islamic ideological interest groups present coloring the world of Indonesian politics, many of them interfering with the policy to be issued, here are some interest groups in Indonesia;

\section{Muhammadiyah}

A group founded by K.H. Achmad Dahlan, who had been active since 1912, with the opinion that the true religion of Islam was to return to the Qur'an and the Hadith. Now Muhammadiyah can be 
regarded as a large interest group, its cadres are spread throughout Indonesia, and it is not uncommon for Muhammadiyah cadres to join the world of Indonesian politics.

\section{Nahdatul Ulama (NU)}

Is a group formed by K.H. Hasyim Asy'ariy, active since January 31, 1926. This group puts forward the principle of maintaining and developing the Ahlussunnah Wal Jamaah in Indonesia. Since 1926 which was originally only in Java, now NU has spread throughout Indonesia. In fact, many of the NU cadres are exploring the world of politics in Indonesia.

\section{Shi'ism}

The flow of Shi'ism that developed in Indonesia is the Shi'a Itsna 'Asyariyyah (Imamiyyah), and has followers of tens of thousands under the banner of IJABI (Association of Jamaah Ahlul Bait Indonesia), based in Jakarta.

\section{Jama'ah Tabligh}

The Jama'ah Tabligh in Indonesia developed since 1952, brought by a group from India led by Miaji Isa. But this movement began to bloom in the early 1970s. They made the mosque as the center of their activities. It is unclear how many they are, because statistically it is difficult to calculate. But clearly, they are everywhere throughout the archipelago. This congregation was founded by Shaykh Muhammad Ilyas bin Muhammad Ismail al-Kandahlawi (13031363). This group has been active since the 1920s in Mewat,
India. The international headquarters for Tabligh is in Nizzamudin, India.

5. Majlis Tafsir Al-Qur'an

It was founded by Abdullah Toufel Saputra, and became active on September 19, 1972. The group is spread in Indonesia and currently has 130 branches. With an opinion to return Muslims to the Koran and Hadith, and erode heresy and khufarat in Muslims.

\section{Front Pembela Islam}

The first leader was KH Cecep Bustomi, the current leader Habib Rizieq Shihab. This group August 17, 1998 until now dragged down several cases involving its leader.

\section{Hizbut Tahrir}

Founded by Sheikh Taqiyuddin AnNabhahani in 1953 in Al-Quds, Jerusalem as the Islamic Political Party, and its first leader was Abdurahman Albagdadi. Hizbut Tahrir has been active since 19821983 by carrying out opinions to initiate the formation of a worldwide Islamic state, aka the Khilafah Islamiyah. Hizbut Tahrir stated that democracy is not Islamic, because democracy is sovereignty in the hands of the people. The implication of the right to make the law is in the hands of the people, not in the hands of God. If so, then democracy is contrary to Islam which recognizes the right to make the law only belongs to God.

\section{Wahabi}

The founder of this movement was Muhammad bin Abdul Wahab (1702-1787 
AD). In Munjid it is stated that their tariqat is called AlMuhammadiyyah and their fiqh adheres to the Hanbali school of thought adapted to Ibn Taimaiyyah's interpretation.

Among the eight Islamic ideological interest groups in Indonesia, there were only four that under Jokowi's reign emerged, the four groups were Muhammadiyah, NU, Hizb utTahrir, and Front Pembela Islam.

\section{Islam and Foreign Policy during the Jokowi Reign}

The world maritime axis is the discourse of President Jokowi and one of Indonesia's foreign policies during his reign. President Jokowi also stressed that in the next five years Indonesia must return to being a maritime nation. The President believes that Indonesia is able to position itself as the world's maritime axis. In President Jokowi's speech (2014) it was stated that: "We have turned our backs on the sea, our backs on the ocean, and our backs on the strait and the bay. This is the time we return everything so that 'Jalesveva Jayamahe', in the sea we actually triumph, as our motto in the past can reverberate again."

Foreign policy when President Jokowi asked to focus on Indonesia's Position as the World Maritime Axis, various forms of efforts have been made, one of them joining Indonesia with the IORA (Indian Ocean Rim Association). ${ }^{10}$ And slowly

\footnotetext{
${ }^{10}$ Minister Retno Marsudi. "Maritime Diplomacy, Economic Diplomacy, and Peace and Humanitarian Diplomacy" in Public Lecture by
}

voicing that Indonesia is the World Maritime Axis, Indonesia is the world's largest maritime power.

Apart from the government's focus on the return of Indonesia as the World Maritime Axis, it can be seen that foreign policy has a relations to democracy. Democracy and foreign policy have a relationship that shows an influence of the democratic process which does not stop at the domestic structure. Indonesia's foreign policy is also influenced by democracy, both at the level of formulation and the making and implementation. The connection between the two is explained by Jorn Dosch that;

"The influence of non-govermental actors in forign policy arena is prominently related to the way in which regime accountability constraints the government's latitude of decisionmaking in foreign affairs. In an authoritarian state regime, accountability tends to be low because the procedures for power transfer are not institutionalized. The continuity of a regime's performance. Hence, accountability does not impose a significant limitation of foreign policy making in authoritarian polities. In contrast, democratization increases regime accountability and, as a result, restricts the regime's leeway in determining and implementing foreign policy goals." 11

Ministry of Foreign Affairs Indonesia, Hasanuddin University, February 22, 2019.

${ }^{11}$ Jörn Dosch, "The Impact of Democratization in the Making of Foreign Policy in Indonesia, Thailand and the Philippines", 
Based on Dosch's explanation, foreign policy is not only the domain of the state or government. The foreign policy provides space for the role of community groups in the government's efforts to respond to domestic issues, both at the global and regional levels of Southeast Asia. This non-state actor has forced the Indonesian government "...to pay more attention to issues such as human rights and environmental matters in foreign affairs and blocked or significantly reshaped governmental initiatives toward other countries." ${ }^{12}$ Things like this have happened since President SBY's government and carried over to the Jokowi government.

One form of freedom during President Jokowi's government was the existence of social movements in the community. Society is free to bring its interests, be it the interests of groups or personal interests. This is a form of democracy in which freedom is in the hands of the society, freedom of expressing aspirations. When demands and interests have been submitted, then back again to the government's response, whether to accept or just ignore the demands and interests conveyed.

Social movement is a persuasive action carried out by the public to influence ideas and policies. Social movements can include formal and informal organizations.

Südostasien aktuell : Journal of Current Southeast Asian affairs 25 (5) (2006), pp. 42-70.

${ }^{12}$ Jörn Dosch, p. 46.
Social movements have the aim to attract and mobilize audiences to strengthen the goals of social movements. ${ }^{13}$

Sari in research on the relations of religion and politics states the peaceful action of Islamic defense is a social movement. ${ }^{14}$ Social movements that arise are from Muslims who are offended by blasphemy cases. The research also categorizes social movements as peaceful movements of Islamic defense including the New Movement type because it began in the 20th century. The study also stated that the Islamic Defending Peace Action wanted legal justice for the blasphemy case of Religion to be processed immediately. Both of these studies show a different but similar context in categorizing demonstrations as a form of social movement. The existence of a social movement with a collective effort by a group of people with the same conviction to make efforts to convey aspirations and protest through demonstrations.

One form is the peaceful actions 411 and 212. The peaceful actions 411 and 212 are a form of demonstration of protests against the blasphemy case by Basuki Tjahaja Purnama. A group of CSOs and the Muslim community protested by holding a demonstration against the course of the

\footnotetext{
${ }^{13}$ Teta Dian Wijayanto \& Dian Purworini, "Respon Pemerintah Pada Aksi Damai 411 dan 212: Analisis Isi Harian Kompas Edisi November 2016 -Desember 2016", Komuniti: Jurnal Komunikasi dan Teknologi Informasi Vol. 10, No. 1 (2018), p. 14 ${ }^{14}$ Teta Dian Wijayanto \& Dian Purworin, p. 14.
} 
case which raised issues in the ranks of government. The action was carried out collectively with the same goal to immediately process the blasphemy case by Basuki. The people felt anxiety in the stability of government and politics in the Indonesian government that led to social movements with peaceful demonstrations of 411 and 212. They had the same beliefs and the same goals, as well as the expectation of protest form through their demonstrations. Peaceful actions carried out with the aim, organization, and the existence of values of hope carried out collectively by the community make this action one of the forms of social movements. ${ }^{15}$

Denial, is an effective action to overcome the image crisis that occurs. This is done because the organization avoids all responsibilities and mistakes that occur. But if the organization knows or the leader has responsibility for mistakes, then this method of denial must be crossed out as a strategy to overcome the crisis (Coombs: 2016). The government, in this case, does not carry out such massive denial. The crisis that occurred to the Government in this peaceful action was not necessarily rejected by the government.

The President in his statement, "Once again, this is also the people need to know, I will not protect Brother Basuki Tjahaja Purnama because it has entered the legal $14-15$. process." ${ }^{16}$ The rejection made by President Jokowi in the above news stated the Government's belief not to be involved in the blasphemy case. The issue of involvement or intervention is also one of the factors arising from the social movements of peaceful actions 411 and 212. In addition to direct rejection, the government also rejects the blame for the existence of other elements involved during the 411 peaceful protest. Allegations of other persons in the action because after the action 411 chaos arose. This certainly makes the government take the fight by accusing other elements for the social movement of the 411 action.

According to the researcher, this rejection by the Government was due to the rise in the issue of partiality related to cases of blasphemy. The case of blasphemy by Basuki Tjahaja Purnama caused an issue with the government. This is due to Basuki being a representative of Jokowi when he was the Governor of Jakarta before becoming President. President Jokowi and his staff are suspected of this issue of partiality. The rejection action carried out by the Government seemed to be very cautious or even the Government could not withstand or strongly reject the issue. The social movement action that was carried out was a form of anxiety of some people regarding the handling of blasphemy cases. Because of the issue of

\footnotetext{
${ }^{16}$ Ihsanuddin, "Pernyataan "Saya Tak Akan Lindungi Ahok" dari Jokowi yang Ditunggutunggu..." in https://nasional.kompas.com/read/ 2016/11/09/09290881/pernyataan.saya.tak.akan.lin dungi.ahok.dari.jokowi.yang.ditunggu-tunggu.? page $=$ all. accessed on 12 November 2019.
} 
government bias in this case, the government's reputation is threatened. The government places restrictions on events that suppress the situation when handling cases of blasphemy. Various parties who along with the Government ranks are trying to limit actions in handling this case.

\section{CONCLUSION}

The conclusion of this research is that during Jokowi's reign there were many interest groups with Islamic ideology that came to the surface, they all brought their interests. Something like this arises because of an issue that heats up, which originated from a case of blasphemy by Basuki Tjahaja Purnama.

The case led to a social movement, in which almost all Muslims in Indonesia united and joined forces to form an action called the 'Aksi Bela Islam'. Then the action becomes a gap for elements of interest groups to bring their interests. Starting from the interest to change the Indonesian government system into the Khilafah, even an action to influence Indonesia's foreign policy.

The government responds to this with the word "not to interfere" in this issue. The government indirectly refused to interfere in matters like this. If you look at Jokowi's style of being independent in determining domestic and foreign policy, then the issue and predictability of the mass movement can only be predicted by the wind and then in the Jokowi Government. Jokowi let him while it does not damage the order of government.

Islam here has an important position, but this all returns to the ruling President. Domestic conditions which cause social unrest cannot affect Indonesia's foreign policy. Even though the Foreign Policy originates from foreign countries, Indonesia still launches its interest to attract the world's attention regarding the issue of the World Maritime Axis.

***

\section{REFERENCES}

Alberthiene Endah, Jokowi Menuju Cahaya, (Surakarta: Tiga Serangkai, 2018).

Jörn Dosch, "The Impact of Democratization in the Making of Foreign Policy in Indonesia, Thailand and the Philippines", Südostasien aktuell : Journal of Current Southeast Asian affairs 25 (5) (2006), pp. 42-70.

Mangadar Situmorang, "Orientasi Kebijakan Politik Luar Negeri Indonesia di Bawah Pemerintahan Jokowi-JK”, Jurnal Ilmiah Hubungan Internasional, Vol. 11 No. 1 (2015), pp. 67-85.

Minister Retno Marsudi. "Maritime Diplomacy, Economic Diplomacy, and Peace and Humanitarian Diplomacy" in Public Lecture by Ministry of Foreign Affairs Indonesia, Hasanuddin University, February 22, 2019. 
Mohammad Erzawan Wijaya, "Pengaruh Politik Luar Negeri Pemerintahan Joko Widodo terhadap Islam di Indonesia", Skripsi (Bandung: Universitas Katolik Parahyangan, 2019).

Rizky Alif Alvian, Ganesh Cintika Putri \& Irfan Ardhani, "Haluan Baru Politik Luar Negeri Indonesia: Perbandingan Diplomasi 'Middle Power' Susilo Bambang Yudhoyono dan Joko Widodo", Jurnal Hubungan Internasional, Vol. 6, No. 2 (2017), pp. 151-168.

Teta Dian Wijayanto \& Dian Purworini, "Respon Pemerintah Pada Aksi Damai 411 dan 212: Analisis Isi Harian Kompas Edisi November 2016 -Desember 2016", Komuniti: Jurnal Komunikasi dan Teknologi Informasi Vol. 10, No. 1 (2018), pp. 11-25.

\section{Website}

DPR RI," Undang-Undang No.42 Tahun 2008 Tentang Pemilihan Umum Presiden dan Wakil Presiden" in http://www.dpr.go.id/dokjdih/ document/uu/UU_2008_42.pdf accessed on 12 November 2019.

Ihsanuddin, "Pernyataan "Saya Tak Akan Lindungi Ahok" dari Jokowi yang Ditunggu-tunggu..." in https:// nasional.kompas.com/read/2016/11 /09/09290881/pernyataan.saya.tak. akan.lindungi.ahok.dari.jokowi.yan g.ditunggu-tunggu.? page=all. accessed on 12 November 2019.

KPU RI, "Hasil Penghitungan Perolehan Suara Dari Setiap Provinsi dan
Luar Negeri Dalam Pemilu Presiden Dan Wakil Presiden Tahun 2014" in https://www.kpu.go.id/koleksigam bar/PPWP_Nasional_Rekapitulasi _2014_-

_New_Final_2014_07_22.pdf accessed on 12 November 2019.

Pribadi Wicaksono, "Buya Syafii Minta Hentikan Bilang Jokowi Kurang Perhatikan Islam" in https://nasional.tempo.co/read/115 2805/buya-syafii-minta-hentikanbilang-jokowi-kurang-perhatikanislam/full\&view $=\mathrm{ok}$ accessed on 12 November 2019.

Wishnugroho Akbar, "Fahri Kicaukan 'Dosa-dosa Jokowi' soal Ideologi dan Persatuan" in https://www. cnnindonesia.com/nasional/201807 23171304-32-316365/fahrikicaukan-dosa-dosa-jokowi-soalideologi-dan persatuan accessed on 12 November 2019. 